\title{
Effect of Storage Duration and Temperature on Hatchability and Egg Weight Loss of Kuroiler Breed of Chicken
}

\author{
Subhash Yadav", Mahesh Datt and Om Prakash Choudhary \\ Department of Livestock Production Management, Sri Karan Narendra Agriculture University, Jobner, Rajasthan, INDIA \\ "Corresponding author: S Yadav; E-mail: subhyadav95@gmail.com
}

Received: 02 April, 2021

Revised: 05 May, 2021

Accepted: 11 May, 2021

\begin{abstract}
The present investigation was carried out to investigate egg weight losses and hatchability of eggs of Kuroiler breed of chicken at poultry farm SKN College of Agriculture, Jobner (Rajasthan). Total 180 fresh eggs of Kuroiler chicken of 25-38 week age were collected for this study and stored for 0,5 and 7 days at two different temperatures i.e. $30 \pm 2^{\circ} \mathrm{C}$ and $20 \pm 2^{\circ} \mathrm{C}$ as per treatment i.e. $T_{1}\left(30^{\circ} \mathrm{C}+0 \mathrm{~d}\right), \mathrm{T}_{2}\left(30^{\circ} \mathrm{C}+5 \mathrm{~d}\right), \mathrm{T}_{3}\left(30^{\circ} \mathrm{C}+7 \mathrm{~d}\right), \mathrm{T}_{4}\left(20^{\circ} \mathrm{C}+0 \mathrm{~d}\right), \mathrm{T}_{5}\left(20^{\circ} \mathrm{C}+5 \mathrm{~d}\right)$ and $\mathrm{T}_{6}\left(20^{\circ} \mathrm{C}+7 \mathrm{~d}\right)$. Treated eggs tray are placed incubator to determine hatchability. Result shows that egg weight loss was maximum (2.06\%) in treatment $\mathrm{T}_{3}$ followed by $\mathrm{T}_{2}$ and $\mathrm{T}_{1}$. The egg weight decreased with increase in storage duration and temperature conditions. In present investigation percentage hatchability (Fertile Egg Set Basis) was found significantly higher (90.70\%) in 5 days stored eggs than 7 days storage $(85.37 \%)$ and 0 day storage $(77.50 \%)$ under cold temperature $\left(20^{\circ} \mathrm{C}\right)$ with fumigation and hatchability of (Total Egg Set Basis) was found significantly higher in eggs that stored for 5 days $(86.67 \%)$ and found lower in 0 days stored eggs $(68.89 \%)$. Duration of storage and temperature significantly $(\mathrm{P} \leq 0.05)$ affected hatchability of eggs (both TES \& FES). Hatchability declines when storage duration is beyond 5 days. Hatchability also found higher in eggs stored at $20^{\circ} \mathrm{C}$ temperature.
\end{abstract}

\section{HIGHLIGHTS}

(0 Hatchability of eggs for 0,5 and 7 days pre-incubation storage was found higher in 5 days $(90.70 \%)$ storage eggs at the temperature of $20^{\circ} \mathrm{C}$

(0 Hatchability was also found higher at $20^{\circ} \mathrm{C}$ as compared to $30^{\circ} \mathrm{C}$ storage temperature.

Keywords: Storage duration, temperature, hatchability, egg weight loss, Kuroiler breed

Poultry plays an important role in producing animal proteins most effectively and economically within the shortest possible time. Poultry is the fastest growing segments of the agricultural sector in India with around eight percent growth rate per annum. India ranks $3^{\text {rd }}$ in egg production and $5^{\text {th }}$ in chicken meat production in the world.

The Kuroiler is the important chicken breed developed in India. Kuroiler is a dual-purpose breed provides meat and eggs (150-200 eggs per year). It can survive on a kitchen and agricultural waste. For hatching eggs pre-incubation period is very important as it affects the hatching egg quality. Collected eggs should be kept in a controlled environment to obtain maximum hatchability. Storage of eggs is a common practice in commercial breeder farms and hatcheries. In general hatcheries eggs set in incubator after 3 to 5 days but in some situation it needs to increase above 7 days. Storage period more than 7 days is cause a delay in embryo development, altered metabolic rate and decline in hatchability (Egbeyale et al., 2013).

Chicken embryo starts to develop just after laying, so fertile eggs have to be stored at particular environmental conditions. During storage environmental conditions

How to cite this article: Yadav, S., Datt, M. and Choudhary, O.P. (2021) Effect of storage duration and temperature on hatchability and egg weight loss of Kuroiler breed of chicken. J. Anim. Res., 11(3): 483-486. Source of Support: None; Conflict of Interest: None 
should be sufficiently cool to prevent embryonic development. For most bird species, the critical temperature for the initiation of embryonic development appears to be about 25 to $27^{\circ} \mathrm{C}$. Relative humidity should be maintained between 70 and $80 \%$ to minimize egg water loss (Khan et al., 2014).

\section{MATERIALS AND METHODS}

The experiment was carried out at the poultry farm, S.K.N. College of Agriculture, Jobner. District- Jaipur (Rajasthan). The area falls in agro-climatic zone III-A (semi-arid plain zone of Rajasthan). The climate of this region is a typically semi-arid, characterized by extremes of temperature during both summer and winters. All the layer birds for research were maintained under deep litter system with 3 sq. feet floor space / bird. The experimental birds belonged to same age group (28- 35 weeks) and the sex ratio or female to male ratio $(10: 1)$ is maintained. The study was conducted during December 2018 to May 2019.

A total of 180 numbers of eggs were selected in three (3) batches the first batch of the eggs were picked up on the first day of the seven days, and stored for 7 days. The second batch was collected two days later and stored for 5 days. The third batch of eggs was also collected five days after collecting the second batch. Third batch of eggs were not stored was considered as fresh eggs (only stored for 6 hours of day). After collection and weighing, the eggs were stored under hot temperature $\left(30^{\circ} \mathrm{C}\right)$ and under cold room temperature $\left(20^{\circ} \mathrm{C}\right)$. Distribution of eggs according to treatment in Table 1. and after the period of storage, eggs were weighing in weighing machine to determine the loss in weight during storage.

Table 1: Distribution of eggs according to treatments

\begin{tabular}{ll}
\hline Treatments Interaction & Symbols \\
\hline Hot temp. $\left(30 \pm 2^{\circ} \mathrm{C}\right)+$ fresh egg. & $\mathrm{T}_{1}$ \\
Hot temp. $\left(30 \pm 2^{\circ} \mathrm{C}\right)+5$ days stored eggs. & $\mathrm{T}_{2}$ \\
Hot temp. $\left(30 \pm 2^{\circ} \mathrm{C}\right)+7$ days stored eggs. & $\mathrm{T}_{3}$ \\
Cold temp. $\left(20 \pm 2^{\circ} \mathrm{C}\right)+$ fresh egg. & $\mathrm{T}_{4}$ \\
Cold temp. $\left(20 \pm 2^{\circ} \mathrm{C}\right)+5$ days stored eggs. & $\mathrm{T}_{5}$ \\
Cold temp. $\left(20 \pm 2^{\circ} \mathrm{C}\right)+7$ days stored eggs. & $\mathrm{T}_{6}$ \\
\hline
\end{tabular}

\section{Incubation process}

All experimental eggs were incubated in an automated electrical incubator at $37.50{ }^{\circ} \mathrm{C}$ to $37.70{ }^{\circ} \mathrm{C}$ and $60-65 \%$ relative humidity with optimum turning. After $18^{\text {th }}$ days the alive embryos were transferred to the hatcher. On $22^{\text {nd }}$ day of incubation chicks were taken out from hatcher and percentage hatchability was recorded.

\section{Egg Weight loss (g)}

Average initial weights of eggs were recorded before storage and final weight recorded after storage of eggs on $1.0 \mathrm{~g}$ sensitive electronic balance. The reduction in egg weight was calculated by difference. The percentage (\%) of weight loss of the eggs was calculated by following formula:

Total weight loss $(\mathrm{g})=$

$$
\frac{\text { Initial weight of egg }- \text { Egg weight after storage }}{\text { Initial weight of egg }} \times 100
$$

\section{Hatchability}

Hatchability is a number of chicks hatched per hundred eggs incubated. Hatchability is a percentage of eggs that hatch successfully after the incubation period of 21 days. Hatchability therefore, basically involves losses due to embryonic death at various stages of development.

Hatchability percentage was estimated on the basis of total egg set i.e. both fertile and infertile included and on the basis of fertile eggs as per following formula:

(i) Hatchability percentage (total eggs set basis): Hatchability on total eggs set (TES) was determined by the ratio of number of chicks hatched and total number of eggs incubated.

Hatchability $(\%)=$

$$
\frac{\text { Number of chick hatched }}{\text { Total number of eggs (both fertile and infertile) }} \times 100
$$

(ii) Hatchability percentage (fertile eggs set basis): Hatchability on fertile egg set (FES) was calculated as the ratio of number of chicks hatched to the total number of fertile eggs incubated. 
Hatchability $(\%)=$

$$
\frac{\text { Number of chick hatched }}{\text { Total number of fertile egg setted }} \times 100
$$

\section{STATISTICAL ANALYSIS}

The experimental data were statistically analyzed using standard statistical methods as per Snedecor and Cochran (1994) using Completely Randomized Design (CRD) with factorial structure. All the data were subjected to analysis of variance. Consequently, a level of $(\mathrm{P} \leq 0.05)$ was used as the criterion for statistical significance.

\section{RESULTS AND DISCUSSION}

\section{Egg weight loss during storage}

Average weight of egg laid by Kuroiler breed was weighed by the $1.0 \mathrm{~g}$ sensitive electronic balance before storage and after storage. Maximum fresh egg weight obtained was 58.60 grams and minimum egg weight was 54.85 gram in the present investigation. Per cent weight loss of eggs in different treatments is given in Table 2.

Table 2: Mean value of eggs weight and eggs weight loss of Kuroiler breed

\begin{tabular}{lllll}
\hline Treatments & $\begin{array}{l}\text { Initial } \\
\text { Weight of } \\
\text { eggs (gram) }\end{array}$ & $\begin{array}{l}\text { Weight of } \\
\text { eggs after } \\
\text { Storage (g.) }\end{array}$ & $\begin{array}{l}\text { Egg weight } \\
\text { loss during } \\
\text { storage(g) }\end{array}$ & $\begin{array}{l}\text { Egg weight } \\
\text { loss(\%) }\end{array}$ \\
\hline $\mathrm{T}_{1}$ & $58.60 \pm 0.03$ & $58.60 \pm 0.03$ & 0.00 & 0.00 \\
$\mathrm{~T}_{2}$ & $54.85 \pm 0.04$ & $54.00 \pm 0.04$ & 0.85 & 1.55 \\
$\mathrm{~T}_{3}$ & $55.75 \pm 0.03$ & $54.60 \pm 0.04$ & $1.15^{*}$ & 2.06 \\
$\mathrm{~T}_{4}$ & $56.50 \pm 0.02$ & $56.50 \pm 0.02$ & 0.00 & 0.00 \\
$\mathrm{~T}_{5}$ & $56.85 \pm 0.02$ & $56.15 \pm 0.03$ & 0.70 & 1.20 \\
$\mathrm{~T}_{6}$ & $57.55 \pm 0.03$ & $56.62 \pm 0.03$ & 0.93 & 1.62 \\
\hline
\end{tabular}

* Significant at $5 \%$ level.

In treatment $\left(\mathrm{T}_{3}\right)$ egg weight loss was significantly $(\mathrm{P} \leq 0.05)$ higher 2.06 per cent in eggs stored for 7 days at $30^{\circ} \mathrm{C}$ temperature. The minimum egg weight loss was found zero per cent in fresh eggs. Highest percentage of eggs weight loss was in 7 days storage eggs followed by 5 days than 0 day of storage. Eggs weight loss was also found to be higher in eggs that stored at temperature $30^{\circ} \mathrm{C}$ as compared to $20^{\circ} \mathrm{C}$. Further analysis revealed that egg weight significantly decreased at increase in storage duration and temperature. Akter et al. (2014) also observed this trend of egg weight losses of chicken as storage duration increased. They found that water loss from eggs during storage is due to temperature of the environment and the storage duration. Basha (2015) reported the weight loss of balady egg ranging from 2.89 to 3.71 gram for the eggs stored for 3 to 7 days, respectively which was higher than present findings. Egbeyale et al. (2013) found that egg weight loss of pullet egg at 3, 6, 9 and 12 days were $0.52,0.87,1.95$ and 1.97 gram, respectively.

\section{Hatchability of eggs of Kuroiler breed}

Hatchability was calculated for different treatments on the basis of total eggs set as well as on the basis of fertile eggs set for eggs of Kuroiler breed. Percentage hatchability (fertile egg set basis) was found higher in 5 days stored eggs $(90.70 \%)$ than 7 days storage $(85.37 \%)$ and 0 days storage $(77.50 \%)$ under $20^{\circ} \mathrm{C}$ temperature. According to statistical analysis duration of storage significantly $(\mathrm{P} \leq 0.05)$ affect the hatchability of eggs. Slightly lower mean percentage hatchability was found at $30^{\circ} \mathrm{C}$ than $20^{\circ} \mathrm{C}$. Hatchability was significantly $(\mathrm{P} \leq 0.05)$ affected by the storage temperature. The finding suggests that hatchability declines when storage duration is beyond 5 days irrespective of the storage temperature. However, eggs stored under high temperature are much more affected. Hatchability of total egg set basis was significantly $(\mathrm{P} \leq 0.05)$ affected by the storage duration and temperature, which was higher in 5 days storage (86.67\%) than for 7 days $(77.78 \%)$ and 0 day $(68.89 \%)$ under cold temperature $\left(20^{\circ} \mathrm{C}\right)$. Interaction effect of temperature and duration also significantly $(\mathrm{P} \leq 0.05)$ affect the hatchability (TES). Hatchability of different treatment group are presented in Table 3.

In the present investigation the hatchability was recorded low at 0 day (fresh) storage (under both temperatures) as compared to 5 and 7 days. This could be due to interaction of environmental factors. These findings were in agreement to report of Hamidu et al. (2010) reported lower hatchability in fresh eggs, may be due to smaller air space than normal air space to facilitate hatching, increased number of open blasto-dermal cells leading to increased early embryonic mortality. Gavril and Usturoi (2012) found that higher 
amount of $\mathrm{CO}_{2}$ in fresh eggs affected hatchability due to higher acidity as the $\mathrm{CO}_{2}$ could not moved out from eggs. Therefore, hatchability tends to be lower in eggs incubated fresh or when at 1 day old. Result of present findings were in agreement with Schmidt et al. (2009) and Egbeyale et al. (2013) who recorded highest value for hatchability percentage for eggs stored for a period of 3 days while the lowest hatchability value was recorded in eggs stored for a period of 12 days. Premavalli and Omprakash (2018) reported that hatchability of Turkey under different storage duration. It was found higher at 4 days storage period and gradually declined with increase in storage duration.

Table 3: Hatchability of eggs fertile egg set basis (FES) and total eggs set basis (TES) for different treatments

\begin{tabular}{lll}
\hline Treatments & $\begin{array}{l}\text { Hatchability \% } \\
\text { (FES) (mean }+ \text { SEm) }\end{array}$ & $\begin{array}{l}\text { Hatchability \% } \\
\text { (TES) }(\text { mean }+ \text { SEm) }\end{array}$ \\
\hline $\mathrm{T}_{1}$ & $76.92 \pm 0.073$ & $66.67 \pm 0.152$ \\
$\mathrm{~T}_{2}$ & $83.33 \pm 0.019$ & $77.78 \pm 0.197$ \\
$\mathrm{~T}_{3}$ & $81.58 \pm 0.169$ & $68.89 \pm 0.211$ \\
$\mathrm{~T}_{4}$ & $77.50 \pm 0.087$ & $68.89 \pm 0.056$ \\
$\mathrm{~T}_{5}$ & $90.70 \pm 0.084$ & $86.67 \pm 0.087$ \\
$\mathrm{~T}_{6}$ & $85.37 \pm 0.076$ & $77.78 \pm 0.183$ \\
\hline P- value & & \\
\hline Duration & $0.000^{*}$ & $0.001 *$ \\
Temperature & $0.006 *$ & $0.000^{*}$ \\
Temp. $\times$ duration & 0.141 & $0.025^{*}$ \\
\hline
\end{tabular}

*Significant at $5 \%$ level.

\section{CONCLUSION}

On the basis of present investigation, it may be concluded that the highest egg weight loss of 2.06 per cent was found in 7 days at $30^{\circ} \mathrm{C}$ temperature. The minimum egg weight loss was found 0.00 per cent in fresh eggs. Highest percentage of egg weight loss was in 7 days followed by 5 days and 0 day of storage, respectively. The egg weight decreased with increase in storage duration and temperature conditions Duration of storage significantly $(\mathrm{P} \leq 0.01)$ affected the hatchability (FES \& TES) of eggs, hatchability (fertile egg set basis) was found to be higher $(90.70 \%)$ in 5 days stored eggs at temperature $\left(20^{\circ} \mathrm{C}\right)$ with fumigation and lower in fresh eggs (72.92\%) at temperature $\left(30^{\circ} \mathrm{C}\right)$. Hatchability was also affected by the storage temperature. It was found to have significantly lower mean percentage in hatchability at $30^{\circ} \mathrm{C}$ than at $20^{\circ} \mathrm{C}$. Hatchability (TES) was also significantly $(\mathrm{P} \leq 0.05)$ affected by the interaction of temperature and duration of storage. Duration of storage and temperature significantly affected the hatchability of eggs. Hatchability declines when storage duration is beyond 5 days. Hatchability also found higher in eggs stored at $20^{\circ} \mathrm{C}$ temperature. For higher hatchability eggs were not set in incubator on the same day of oviposition or storage period of more than 5 days.

\section{REFERENCES}

Akter, Y., Kasim, A., Omar, H. and Sazili, A.Q. 2014. Effect of storage time and temperature on the quality characteristics of chicken eggs. J. Food Agric. Environ.,12(3\&4):87-92.

Basha A.H. 2015. Effect of storage period on egg weight loss, hatching weight and hatchability percentage of incubated Egyptian Balady eggs. Alex. J. Vet. Sci., 47:216-220.

Egbeyale, L.T., Bosa, M.K., Sogunle, O.M and Adeleye, O.O. 2013. Effect of pre-incubation storage periods on weight loss, embryonic development and hatchability of pullet eggs. Pac. J. Sci. Tech., 14(2): 416-424.

Gavril, R. and Usturoi, M.G. 2012. Effect of storage time and temperature on hen egg quality. Seria Zootehnie, 57: 221229.

Hamidu J.A., Rieger A.M., Fasenko G.M. and Barreda D.R. 2010. Dissociation of chicken blastoderm for examination of apoptosis and necrosis by flow cytometry. Poult. Sci., 89: 901-909.

Khan, M.J.A., Khan, S.H., Bukhsh, A., Amin, M. 2014. The effect of storage time on egg quality and hatchability characteristics of Rhode Island Red (RIR) hens. Vet. Arh., 84(3): 291-303.

Premavalli, K. and Omprakash, A.V. 2018. Effect of strain and pre-incubation storage period on the hatchability and embryonic mortality in Turkey. Int. J. Chem. Stud., 6(1): 765-767.

Snedecor, G.W. and Cochran, W.G. 1994. Statistical method. $8^{\text {th }}$ Ed., Oxford and IBG Publication Co., New Delhi, India. 